\title{
PERAN PENGABDIAN MASYARAKAT MELALUI PENGUATAN KELUARGA, KELEMBAGAAN SOSIAL DAN DESA DI MASA PANDEMI COVID-19
}

\author{
Avin Wimar Budyastomo \\ Saipullah Hasan \\ Prodi Komunikasi dan Penyiaran Islam, \\ Fakultas Dakwah, IAIN Salatiga \\ Jalan. Lingkar Salatiga Km. 02. Pulutan. Kecamatan Sidorejo. Kota Salatiga 50716 \\ Salatiga, Jawa Tengah, Indonesia \\ avin@iainsalatiga.ac.id \\ saifulhasan@iainsalatiga.ac.id
}

\begin{abstract}
ABSTRAK
Kegiatan pengabdian kepada masyarakat merupakan kegiatan yang wajib dilaksanakan oleh dosen untuk melaksanakan tri dharma perguruan tinggi. Kegiatan pengabdian kepada masyarakat ini merupakan suatu kegiatan yang sangat berbeda dengan kegiatan sebelumnya, yakni ditengah pandemik Covid - 19 yang menuntut semua harus menggunakan metode daring. Namun itu tidak menghambat adanya kegiatan pengabdian kepada masyarakat. Selanjutnya, tantangan utama dalam kegiatan ini adalah peraturan dari pemerintah daerah untuk melaksanakan semua kegiatan secara daring. Kegiatan yang dilaksanakan saat ini adalah memberikan pelatihan kepada masyarakat dan remaja di Desa Sidomukti Kecamatan Bandungan Kabupaten Semarang. Adapun kegiatan yang dilakukan adalah dibidang keagamaan, kesehatan, ekonomi, social budaya dan pariwisata. Tujuan utama adalah sebagai kegiatan pengembangan masyarakat sesuai arahan pembangunan manusia (Human Development), mencapai target dan sasaran millenium development goals (MDGS), kompetensi, potensi, sumber daya, dan kemampuan lingkungan dalam wadah kerjasama masyarakat, pemerintah, swasta, dan lembaga lainnya. Hasil yang didapat dalam kegiatan ini adalah terciptanya masyarakat yang mandiri yang dapat menggunakan aset disekitarnya untuk meningkatkan perekonomian masyarakat setempat.
\end{abstract}

Kata Kunci: Covid-19; Masyarakat; MDGS

\section{PENDAHULUAN}

Kabupaten Semarang adalah salah satu Kabupaten di Provinsi Jawa
Tengah yang mempunyai obyek wista cukup banyak dan bervariasi. Berdasarkan data yang diperoleh 
peneliti, tercatat terdapat sekitar 22 obyek wisata di Kabupaten Semarang baik dengan obyek wisata alam maupun wisata buatan manusia. Salah satu obyek yang menjadi tempat pengabdian masyarakat tersebut adalah Desa Sidomukti Kecamatan Bandungan Kabupaten Semarang

Desa Sidomukti, atau yang juga dikenal oleh masyarakat Jawa Tengah sebagai surganya kabupaten Semarang ini memiliki sejarah panjang bahkan sejak sebelum Indonesia merdeka pada tahun 1945. Dengan dipilihnya Lurah pertama yaitu Pak Bajing atau biasa juga dipanggil Lurah Bajing pada 1930, membuat Desa Sidomukti menjadi salah satu Desa tertua di Jawa Tengah. Desa yang memiliki ciri khas tanah pertaniannya yang subur ini tak lepas dari perhatian masyarakat luar daerah karena keindahan alamnya yang sejuk nan Asri. Menjadikan Desa Sidomukti ini menjadi salah satu Desa rujukan Destinasi Wisata bagi masyarakat khususnya Jawa Tengah yang ingin merasakan langsung indahnya suasana pedesaan yang asri.

Secara letak geografisnya desa Sidomukti terletak diketinggian $1200 \mathrm{~m}$ di atas permukaan laut. Jarak pemerintahan desa menuju kecamatan adalah $2 \mathrm{~km}$, jarak dari pusat pemerintahan desa menuju kabupaten adalah $10 \mathrm{~km}$, sedangkan jarak pusat pemerintahan desa menuju ibukota propinsi adalah $26 \mathrm{~km}$.

Jumlah penduduk Desa Hal| 20

Sidomukti seluruhnya 5589 jiwa, yang terdiri dari perempuan 2807 jiwa dan laki-laki 2782 jiwa. Serta jumlah kepala keluarga adalah 1535 KK.

Desa Sidomukti terdiri 6 Dusun/Dukuh yakni: Dukuh Sidomukti, Dukuh Krandegan, Dukuh Geblog, Dukuh Kluwihan, Dukuh Tegalsari, dan Dukuh Gerpetung.

Jika ditinjau dari segi keadaan sosial, warga Desa Sidomukti merupakan kelompok masyarakat yang religius, di mana kegiatan-kegiatan keagamaan sangat dominan dalam kehidupan bermasyarakat. Sebagian besar penduduk Desa Sidomukti beragama Islam.

Desa Sidomukti mempunyai 8 bangunan masjid, 18 bangunan musholla. Aktivitas keagamaan berupa pengajian, berjanjen, yasinan dan tahlilan, serta baca al-Qur'an dan perkumpulan organisasi keagamaan senantiasa dilaksanakan secara rutin.

Keadaan

perekonomian masyarakat desa Sidomukti berada di sektor pertanian, namun sektor peternakan dan industri juga menjadi penunjang perekonomian di Desa Sidomukti. Karena pertanian 
merupakan merupakan salah satu mata pencarian yang pokok karena daerah yang subur, berada di lereng gunung ungaran serta daerahnya yang subur untuk bercocok tanam.

Selain mata pencaharian pokok tersebut, ada sebagian penduduk yang mencari mata pencaharian yang lain diantaranya sebagai buruh dan berdagang, karena di Desa Sidomukti terdapat wisata alam yaitu umbul Sidomukti.

Kawasan Taman Renang Alam Umbul Sidomukti berdiri di atas lahan seluas 32 hektar yang dikelola langsung olah PT. Panorama Agro Sidomukti. Taman Renang Alam Umbul Sidomukti ini didesain secara unik dengan gaya tradisional minimalis namun memenuhi semua aspek kenyamanan pengunjung. Taman Renang Alam Umbul Sidomukti menggunakan konstruksi bangunan mengikuti punden berundak yang menggunakan tumpukan batu alam yang seolah-olah kawasan wisata Taman Renang Alam Umbul Sidomukti sudah lama ada.

Sumber mata air Taman Renang Alam Umbul Sidomukti berasal dari lereng Gunung Ungaran yang mengalir sepanjang tahun dan Taman Renang Alam Umbul Sidomukti memanfaatkan “Tuk Ngetihan" yaitu air yang memancar keluar dari bawah tanah yang terjadi karena adanya perbedaan ketinggian antara sumber mata air dengan titik keluarnya.

Kawasan desa yang memiliki Hal|21 daya tarik terhadap wisatawan lokal, maupun luar negeri yang mengunjungi kawasan tersebut setidaknya dapat memberikan kenyamanan bagi para wisatawan, seperti halnya infrastruktur yang bagus (jalan), dan ketersedian transportasi, sehingga lebih mempermudah para wisatawan mengunjungi tempat-tempat wisata yang ada di desa-desa (Prilosadoso et al., 2017).

Selanjutnya terlepas dari gambaran desa Sidomukti, kegiatan pengabdian kepada masyarakat merupakan salah satu unsur utama dalam Tri Dharma Perguruan Tinggi yang wajib dilaksanakan oleh setiap dosen. Banyak ragam yang dapat dilakukan oleh dosen dalam melaksanakan kegiatan pengabdian kepada masyarakat, salah satunya adalah memberikan sosialisasi ataupun mengadakan pelatihan (Sitohang \& Endang, 2020).

Kegiatan Pengabdian pada Masyarakat merupakan wujud nyata dari penerapan ilmu yang bersifat siklus/berkesinambungan yang dilaksanakan dengan baik, benar, sistematis dan konsisten. 
Tujuan utama dalam kegiatan pengabdian masyakat ini adalah untuk mengembangkan potensi desa, meningkatkan perekonomian warga, menyelesaikan permasalahan yang ada di tengah masyarakat.

Manfaat yang didapatkan dalam kegiatan ini adalah dapat menyalurkan informasi ke masyarakat melalui program pengabdian masyarakat. Selain itu dapat mengetahui secara langsung permasalahan yang ada dimasyarakat, mengetahui asset desa yang belum dimanfaatkan secara maksimal, dan mengetahui budaya masyarakat setempat yang masih dijaga dan dilestarikan.

Kegiatan seperti ini selalu dihubungkan dengan literasi informasi, yakni suatu kesatuan individu dalam penyerapan informasi yang akan digunakan untuk menemukan, mengevaluasi, dan menggunakan informasi tersebut agar lebih efisien (Afrina et al., 2020).

Kegiatan Pengabdian kepada Masyarakat ini dilaksanakan di Dusun Tegalsari, Desa Sidomukti, Kecamatan Bandungan, Kabupaten Semarang.

Dusun Tegalsari merupakan salah satu dusun yang masuk administrasi Desa Sidomukti yang memiliki asset berupa pertanian dan pariwisata. Pertanian yang dikerjakan oleh warga adalah sayuran dan bunga mawar. Sedangkan asset pariwisata yang dimiliki adalah pemandian alam Sidomukti. Selain itu udara di dusun Hal| 22 tersebut sangatlah sejuk dan dingin.

Ragam kegiatan yang dapat dilakukan adalah pembinaan di bidang agama, kesehatan, pertanian, pariwisata, sosial dan budaya.

Dalam kegiatan pengabdian ini juga dapat menjalin komunikasi yang efektif dengan masyarakat secara langsung dilapangan dan juga dapat mengenai permasalahan yang ada di tengah masyarakat (Budyastomo, 2018).

\section{PEMBAHASAN}

Kegiatan yang telah dilaksanakan di Dusun ini adalah adalah sebagai berikut:

1. Keagamaan

Mayoritas masyarakat di Dusun Tegalsari memeluk agama Islam. Masyarakat disana bisa dikatakan masyarakat yang agamis karena terdapat berbagai macam kegiatan keagamaan rutinan yang dilakukan. Biasanya kegiatan rutinan tersebut dilaksanakan di setiap RT, di mushola maupun di masjid yang dapat diikuti oleh seluruh warga Dusun Tegalsari. Kegiatan keagaman rutinan tersebut meliputi yasinan, dzibaan, 
dan khotmil qur'an. Kegiatan keagamaan rutinan ini sangat positif dikarenakan selain memperdalam ilmu keagamaan masyarakat juga dapat mempererat tali persaudaraan berbagai elemen masyarakat di desa Sidomukti.

a. Yasinan

Yasinan sebagai sebuah agenda keagamaan yang ditransformasikan ke dalam kehidupan sosial kemasyarakatan dalam berbagai aspek kehidupan, yaitu aspek kebersamaan, gotong-royong, kepekaan terhadap dinamika sosial, kepedulian dan saling menghargai antar tetangga dan masyarakat (Hayat, 2014a).

Pengajian yasinan merupakan suatu tradisional setempat yang harus dipelihara, dijaga dan dilaksanakan sebagai ungkapan syukur kepada Allah SWT dan sebagai media dakwah islamiyah yang efektif (Hayat, 2014b).

Yasinan merupakan pembacaan ayat-ayat suci al-Qur'an untuk memohonkan rahmat dan ampunan bagi arwah orang yang meninggal (Mukhlason, 2021).

Posisi Pengabdian kepada Masyarakat pada kegiatan yasinan adalah melakukan pendampingan pelaksanaan yasinan bapak-bapak,

ibu-ibu, dan remaja. Tujuan utama pendampingan ini adalah memberikan koreksi jika ada jamaah yang salah dalam membaca Hal| 23 Al Quran. Kegiatan yasinan dapat dilihat pada Gambar 1.

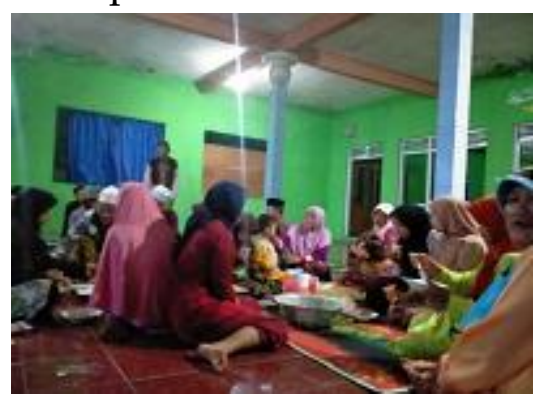

Gambar 1.

Kegiatan Yasinan

b. Dziba'an

Merupakan suatu doa-doa, puji- pujian dan penceritaan riwayat Nabi Muhammad SAW yang biasa dilantunkan dengan irama atau nada (Faizal, 2019).

Posisi Pengabdian kepada Masyarakat untuk kegiatan ini juga melakukan pendampingan dan pengarahan tentang pembacaan sholawat Nabi Muhammad SAW. Kegiatan Dziba'an dapat dilihat pada Gambar 2.

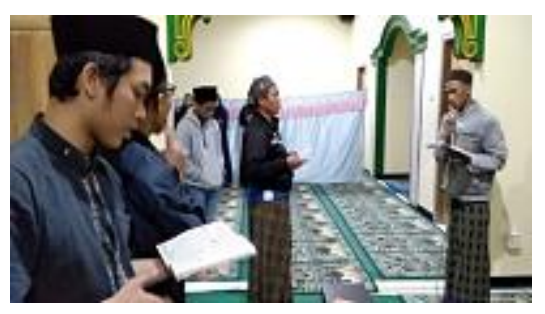

Gambar 2.

Kegiatan Dziba'an 


\section{c. Khotmil Qur'an}

Khotmil qur'an atau biasa disebut khatam qur'an adalah sebuah istilah bagi ritual yang mentradisi dan berisi pembacaan ayat-ayat alqur'an mulai dari surat al-fatihah hingga surat annaas sesuai dengan urutan yang terdapat dalam mushaf atau jamaah (Mustafa \& Citra, 2019).

Kegiatan Khotmil Quran dilakukan untuk memperlancar bacaan dalam membaca $\mathrm{Al}$ Quran dan juga dapat mempererat tali persaudaraan antar jamaah.

Posisi pada PkM ini adalah melakukan pendampingan dan menyimak bacaan Al Quran dari jamaah. Kegiatan Khotmil Quran dapat dilihat pada Gambar 3.

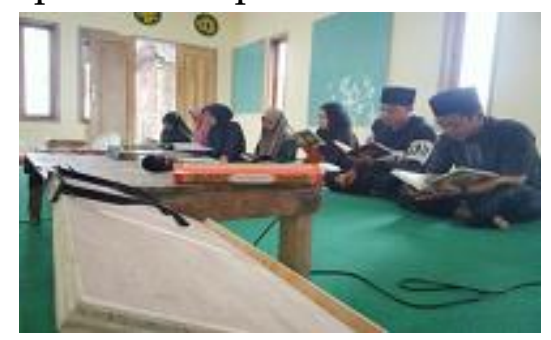

Gambar 3.

Kegiatan Khotmil Quran
Pada kegiatan ini dibantu oleh mahasiswa IAIN Salatiga memberikan bimbingan belajar untuk anak sekolah dari SD Hal| 24 hingga SMA. Kegiatan ini dilaksanakan guna membantu siswa dalam belajar dan menyelesaikan tugas sekolahnya. Kegiatan bimbingan belajar dapat dilihat pada Gambar 4.

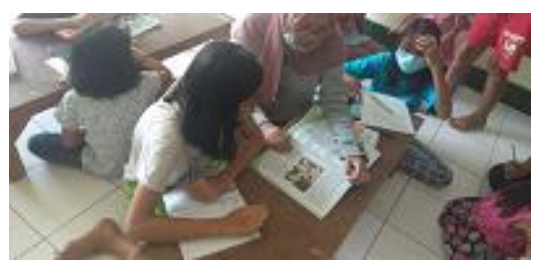

Gambar 4.

Kegiatan Bimbingan Belajar

b. Bimbingan di Madrasah Diniyah pada kegiatan ini memberikan bimbingan kepada anak-anak tentang baca tulis Al Quran. Kegiatan ini berkolaborasi dengan mahasiswa IAIN Salatiga saat melakukan kegiatan KKN. Adapun bimbingan di Madrasah Diniyah dapat dilihat pada Gambar 5.

2. Pendidikan

Selain melakukan PkM dibidang keagaman, selanjutnya kegiatan pendidikan, yakni:

a. Bimbingan Belajar 


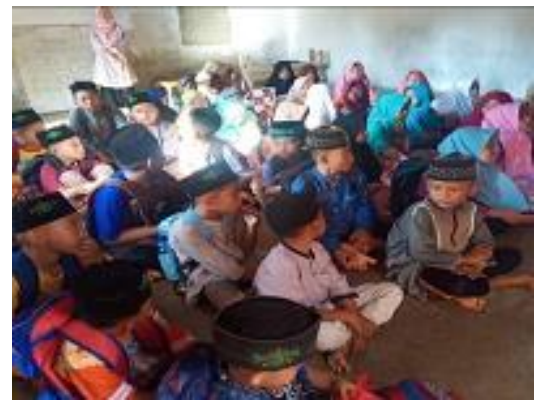

Gambar 5.

Bimbingan di Madrasah Diniyah

c. Pendidikan Gemar Menabung

Kegiatan gemar menabung adalah suatu kegiatan yang diperuntukan untuk menciptakan gemar menabung.

Menabung merupakan suatu kegiatan yang bermanfaat untuk masa depan. Sosialisasi menabung sejak usia dini ini menargetkan anak-anak Desa Sidomukti. Maksud dari sosialisasi ini adalah untuk memberikan pemahaman kepada anak-anak Desa Sidomukti bahwa menabung merupakan kegiatan yang sangat bermanfaat untuk masa depan.

Dengan adanya sosialisasi tentang pentingnya menabung pada usia dini saya berharap kepada anak-anak dapat termotivasi untuk menabung. Selain itu, timbulnya kesadaran anak-anak Desa Sidomukti untuk dapat berperilaku hemat dan menyisihkan sebagian uang mereka untuk menabung.

Dalam kegiatan pengabdian masyarakat ini menggandeng Hal| 25 remaja karang taruna untuk mengadakan sosialisasi kepada anak-anak pentingnya menabung. Harapannya agar generasi muda dapat memenejemen keuangannya secara bijak. Kegiatan Sosialisasi gemar menabung dapat dilihat pada Gambar 6.

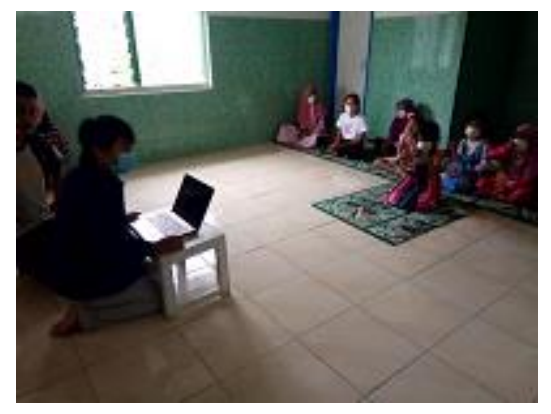

Gambar 6.

Sosialisasi Gemar Menabung

3. Kesehatan

Pada kegiatan Pengabdian kepada Masyarakat ini memberikan sosialisasi terhadap kesehatan di masyarakat. adapun kegiatan yang dapat dilakukan adalah sebagai berikut:

a. Sosialisasi Covid 19

Corona virus adalah suatu kelompok virus yang dapat menyebabkan penyakit pada hewan atau manusia. 
Beberapa jenis corona virus diketahui menyebabkan infeksi saluran nafas pada manusia mulai dari batuk pilek hingga yang lebih serius seperti Middle East Respiratory Syndrome (MERS) dan Severe Acute Respiratory Syndrome (SARS) (Yunus \& Rezki, 2020).

Pencegahan penyebaran virus Covid-19 dapat dilakukan dengan penyemprotan cairan desinfektan pada bendabenda sekitar. Disinfektan menjadi salah satu kunci dalam pencegahan penyebaran virus corona penyebab COVID-19. Namun, harus diperhatikan penggunaannya dengan benar. Disinfektan berfungsi mem-bunuh segala mikro organisme baik virus maupun bakteri, pada objek permukaan benda mati. Bahan disinfektan berbeda dengan antiseptik baik secara tujuan, dosis, dan teknik yang digunakan. Desinfektan biasanya mengandung glutaral dehid dan formal dehid. Penggunaan zat-zat tersebut biasanya digunakan pada rumah sakit dan laboratorium. Namun pada situasi penyebaran virus Hal|26 Covid-19 saat ini dapat digunakan di rumah dengan pembuatan sederhana (Larasati \& Haribowo, 2020).

Kegiatan ini memberikan gambaran mengenai virus Covid-19, bahaya, dan cara memutus rantai virus covid19. Kegiatan ini bekerja sama dengan mahasiswa KKN IAIN Salatiga dan perangkat desa. Adapun kegiatan sosialisasi Covid-19 dapat dilihat pada Gambar 7.

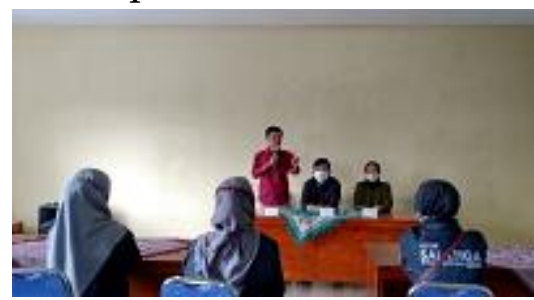

Gambar 7.

Sosialisasi Covid-19

b. Pembagian Masker

Kegiatan Pengabdian kepada Masyarakat untuk selanjutnya adalah pembagian Masker gratis kepada warga. Hal ini perlu dilakukan untuk melindungi warga dari covid-19. 
Kegiatan pembagian masker dapat dilihat pada Gambar 8.

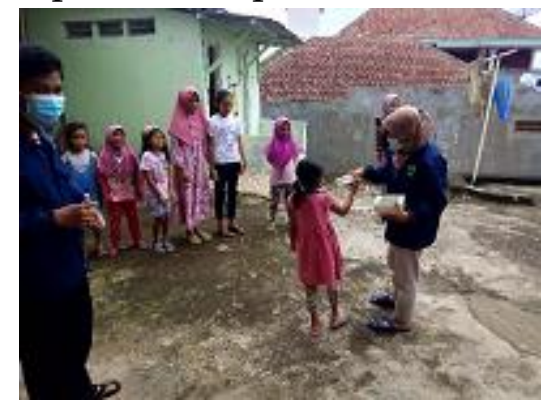

Gambar 8.

Kegiatan Pembagian Masker

c. Pemasangan Hand Sanitiser dan edukasi cuci tangan

Untuk mendukung pemerintah dalam penanggulangan pandemik covid19 , perlu diterapkan protokol kesehatan yang ketat, salah satunya adalah penyediaan hand Sanitizer dan edukasi gerakan mencuci tangan.

Tujuan program ini adalah untuk memberikan pe-ngetahuan masyarakat tentang cara pembuatan disenfektan dan penggunaan atau pe-nyemprotan disenfektan secara tepat. Cairan disenfektan hanya disemprotkan kepada benda mati yang berada didalam rumah ataupun sekitar rumah. Permasalahan yang kami akan berikan solusi pada kegiatan ini yaitu mengadakan sosialisasi dan pelatihan pembuatan desinfektan sebagai upaya pemutusan rantai Hal| 27

penyebaran Covid-19. Pembuatan des-infektan relatif mudah dengan bahan murah dan terjangkau, namun penggunaan yang tidak tepat dapat menimbulkan resiko penyakit bagi masyarakat. Olehnya perlu dilakukan kegiatan pelatihan pada masyarakat tentang pembuatan desinfektan secara tepat. Pelatihan yang efektif harus dirancang sesuai dengan kemampuan masyarakat baik dalam hal materi maupun waktu pelaksanaan.

Pelaksanaan pelatihan
diawali
pengkondisian awal atau memberikan motivasi dan arahan pada peserta untuk semangat mengikuti kegiatan. Suasana yang kondusif dapat tercipta jika kondisi awal peserta dan ruang kegiatan terkondisi dengan baik. Olehnya, tim pengabdian masyarakat ini 
merancang metode pelatihan secara cermat untuk mencapai tujuan yang diharapkan.

$$
\text { Adapun kegiatan }
$$

pemasangan hand sanitizer dapat dilihat pada Gambar 9.

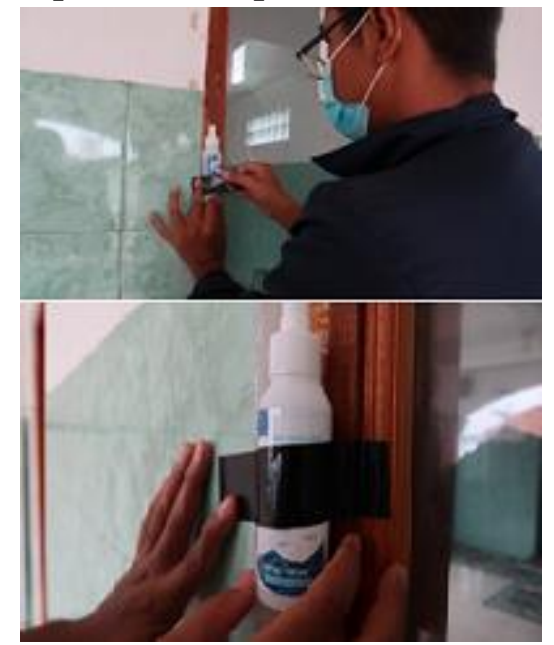

Gambar 9.

Pemasangan Hand Sanitizer

Selanjutnya kegiatan
edukasi gerakan mencuci
tangan dapat dilihat pada Gambar 10.

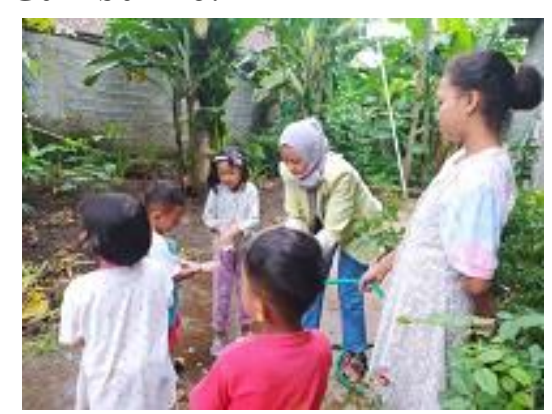

Gambar 10.

Kegiatan Edukasi Gerakan Mencuci Tangan
4. Pertanian

Walaupun bidang pertanian bukan latar belakang pendidikan penulis, namun Hal| 28 dapat memberikan sumbangsihnya kepada masyarakat mengenai pendampingan langsung tata cara menanam yang baik dan benar sehingga hasilnya lebih cepat dipanen. Pelatihan ini diberikan untuk tingkat remaja agar lebih menyukai pertanian. Dari hasil pengamatan dilapangan, remaja desa Sidomukti sangat antusias mengikuti kegiatan pelatihan ini. Kegiatan pelatihan pertanian dapat dilihat pada Gambar 11.

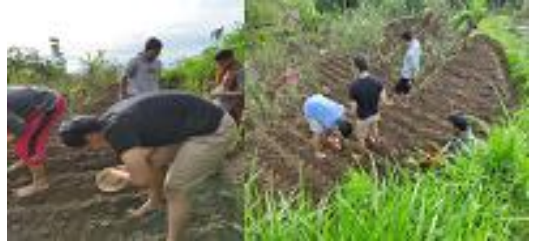

Gambar 11.

Kegiatan Pelatihan Pertanian

Kegiatan pelatihan pertanian ini praktek secara langsung dengan menanam bibit jagung hibrida pada lahan perkebunan warga yang kosong.

Selain melakukan pelatihan pertanian, Kegiatan yang lain yang dapat dilakukan adalah memberikan sosialisasi tentang 
penghijuan di lahan kosong. Manfaat dari kegiatan ini adalah untuk memaksimalkan lahan kosong untuk keindahan lingkungan desa. Kegiatan ini dilakukan oleh remaja desa Sidomukti. Adapun kegiatannya adalah penanaman tanaman perdu dalam polybag dan penataan taman. Kegiatan penghijuan dapat dilihat pada Gambar 12.

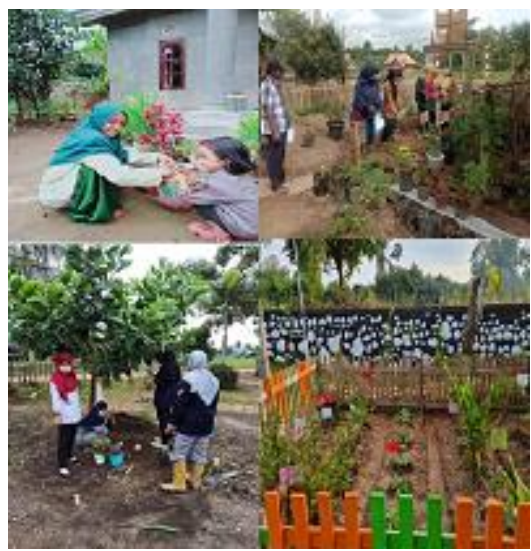

Gambar 12.

Kegiatan Penghijaun

5. Pariwisata

$$
\text { Selanjutnya Pengabdian }
$$
kepada Masyarakat dibidang pariwisata yang dapat dilakukan adalah membuat sebuah video profil desa Sidomukti yang menawarkan panorama yang sangat indah dan eksotik. Pembuatan Video ini juga melibatkan remaja desa Sidomukti. Mereka ditugaskan untuk membuat skrip/naskah video, pengambilan gambar, dan pengemasan video. Hasil yang didapatkan ini akan digunakan sebagai media promosi desa Hal| 29 Sidomukti ke masyarakat umum guna meningkatkan perekonomian masyarakat. Proses pengambilan dokumentasi profil desa dapat dilihat pada Gambar 13.

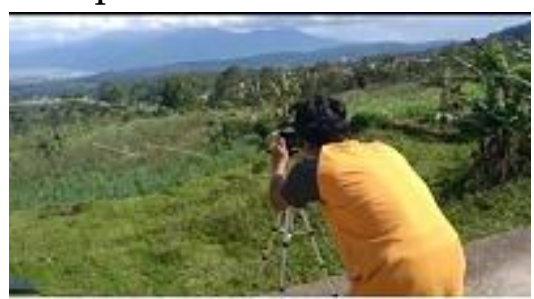

Gambar 13.

Proses Pengambilan Dokumentasi Profil Desa

Proses pengambilan gambar untuk dokumentasi dilakukan di sebuah bukit agar mendapatkan gambar yang bagus. Setelah mengambil gambar, selanjutnya adalah proses editing video. Proses editing video ini menampilkan panorama, pertanian, pariwisata, pemerintahan desa, dan batasbatas desa. Proses editing video dapat dilihat pada Gambar 14. 


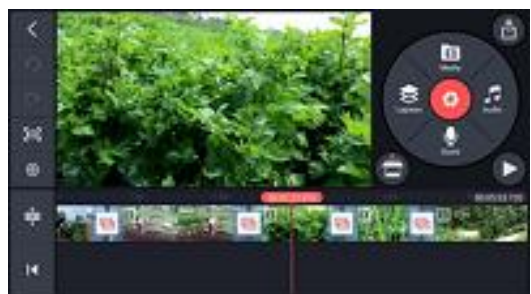

Gambar 14.

Proses Editing Video

Pada gambar 14 dijadikan sebagai cover video yang menampilkan

panorama/pemandangan Desa

Sidomukti pada pagi hari.

Setelah melakukan editing video selanjutnya adalah proses audiensi dengan perangkat desa mengenai evaluasi hasil editing video. Hal ini perlu dilakukan untuk mengetahui penilaian atau saran mengenai video profil ini sebelum di launching ke masyarakat umum. Hasil video profil desa dapat dilihat pada Gambar 15.

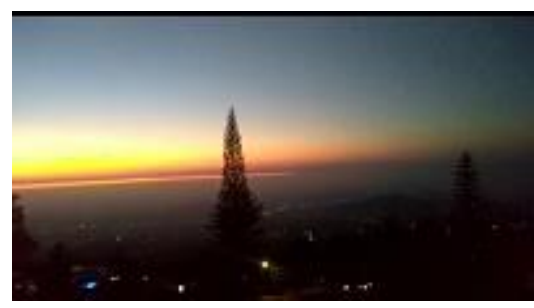

Gambar 15.

Hasil Video Profil Desa

6. Sosial dan Budaya

Masyarakat desa Sidomukti masih memegang teguh prinsip gotong royong. Kegiatan gotong royong dilaksanakan setiap hari minggu pertama dan ke empat tiap bulan. Kegitan ini diikuti oleh remaja desa dan bapak-bapak. Sedangkan untuk ibu-ibu juga membantu Hal| 30 dengan membuat dan menyiapkan makanan kecil dan minuman. Semua masyarakat guyup rukun dalam kegiatan ini. Mereka bekerja sama membersihkan halaman rumah, kebun, parit, jalan kampung, dan membersihkan pos kamling. Pengabdian yang dapat dilakukan adalah ikut serta kegiatan gotong royong bersama warga. Kegiatan gotong royong dapat dilihat pada Gambar 16.

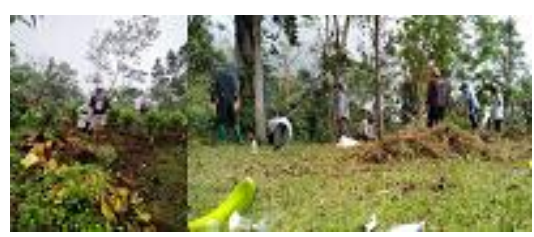

Gambar 16.

Kegiatan Gotong Royong Bersama Warga

Selain

gotong

royong membersihkan kebun dan jalan desa, kegiatan yang lainnya adalah membantu warga dalam penyaluran bantuan tekmon(tandon air) dan pengadaan sumur bor. Bantuan ini berasal dari pemerintah desa. Adapun kegiatan penyaluran dapat dilihat pada Gambar 17. 


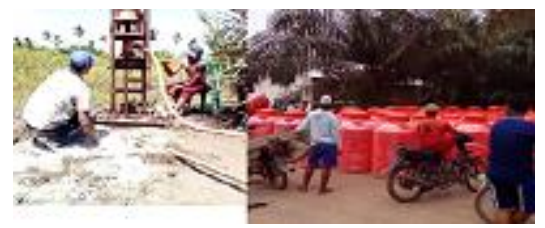

Gambar 17.

Kegiatan Penyaluran Bantuan

Selanjutnya adalah kegiatan budaya. Masyarakat desa Sidomukti masih menyelenggarakan kegiatan sadranan sebagai tradisi tahunan yang sudah ada sejak dahulu. Tradisi Sadranan merupakan suatu kegiatan tahunan yang dilakukan oleh masyarakat setempat untuk membersihkan makam dan mendoakan leluhur masing-masing agar mendapatkan tempat yang baik di sisi Tuhan Yang Maha Esa(Arifah, 2020). Pengabdian kepada Masyarakat yang dapat dilakukan disini adalah ikut nguri-uri budaya desa Sidomukti yakni dengan cara ikut serta dalam kegiatan sadranan. Kegiatan sadranan dapat dilihat pada Gambar 18.

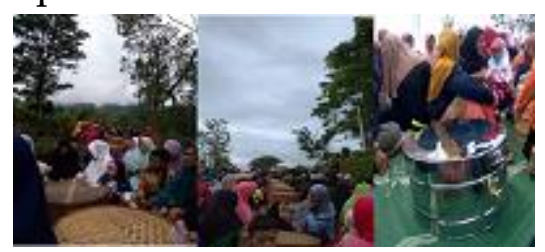

Gambar 18.

Kegiatan Sadranan

\section{SIMPULAN}

Kegiatan pengabdian kepada masyarakat merupakan kegiatan wajib yang dilaksanakan oleh setiap dosen dalam melaksanakan Tri Dharma
Perguruan Tinggi. Kegiatan PkM ini dapat dilakukan dengan berbagai model, salah satunya adalah melakukan pendampingan.

Dalam kegiatan pengabdian Hal| 31 kepada masyarakat ini dilakukan dengan cara pendampingan dan memberikan pelatihan kepada masyarakat desa Sidomukti.

Hasil yang didapatkan dalam kegiatan ini adalah respon yang positif dan hangat dari masyarakat desa Sidomukti. Mereka sangat senang dengan kehadiran kami. Selain itu dapat mengetahui kegiatan masyarakat secara langsung dilapangan serta mengetahui budaya lokal yang masih dijaga dan dilestarikan.

\section{KEPUSTAKAAN}

Afrina, C., Adripen, A., Eliwatis, E., Rikarno, R., \& Hanafi, B. P. (2020). BATOBOH Jurnal Pengabdian Pada Masyarakat. Batoboh, 5(1), 4655. https://journal.isipadangpanjang.ac.id/index.php/Ba toboh

Arifah, D. N. (2020). Nilai-Nilai

Pendidikan Islam Dalam Tradisi

Sadranan Di Dukuh Kadipiro Desa

Genting Kecamatan Cepogo

Kabupaten Boyolali Tahun 2020 .

http://e-

repository.perpus.iainsalatiga.ac.id /8310/2/SKRIPSI- Desi Nur Arifah.pdf

Budyastomo, A. W. (2018). Bentuk Bahasa Komunikasi Dalam Seni Grafiti Sebagai Media 
Penyampaian Pesan (Studi Kasus: Padepokan Grafiti Salatiga).

Batoboh, 3(2), 146-156.

https://journal.isi-

padangpanjang.ac.id/index.php/Ba toboh

Faizal, M. (2019). Kajian Kelompok

Shalawat Diba'i Dan Barzanji

Kelompok As-Salamah Di Dusun

Bamakalah, Pamoroh, Kadur,

Pamekasan. Jurnal Al-Makrifat, 4(2), 56-69.

http://ejournal.kopertais4.or.id/tap alkuda/index.php/makrifat/article/ view/3456/2576

Hayat. (2014a). Strategi Dakwah Nu

Dalam Membangun Mental Dan

Karakter Masyarakat. Jurnal

Walisongo, 22(2), 297-320.

http://journal.walisongo.ac.id/inde

x.php/wali/article/view/192

Hayat. (2014b). Pengajian Yasinan

Sebagai Strategi Dakwah NU

Dalam Membangun Mental Dan

Karakter Masyarakat . Jurnal

Walisongo, 22(2), 297-320.

https://journal.walisongo.ac.id/ind

ex.php/walisongo/article/view/268/

249

Larasati, A. L., \& Haribowo, C. (2020).

Penggunaan Desinfektan dan

Antiseptik Pada Pencegahan

Penularan Covid-19 di Masyarakat.

Majalah Farmasetika, 5(3), 137-145.

https://doi.org/10.24198/mfarmaset

ika.v5i3.27066

Mukhlason, F. (2021, March 15).

Yasinan, Tahlilan dan Kenduri

Kematian: Pengertian, Dalil, dan Pro-
Kontra. Nurmedina.

https://nurmedina.com/keislaman/

yasinan-tahlilan-dan-kenduri-

kematian-pengertian-dalil-dan-

pro-kontra/

Hal| 32

Mustafa, A., \& Citra, S. Y. (2019).

Konstribisi Khotmil Qur'an Dalam

Meningkatkan Motivasi Belajar

Membaca Al-Qur'an Di MA Darul

Faizin Assalafiyah Catak Gayam

Mojowarno Jombang. Inovatif, 5(2), 104-135.

http://jurnal.staih.ac.id/index.php/i novatif/article/view/112/84

Prilosadoso, B. H., Sutedjo, A., \&

Soewasta, M. (2017). Media

Pembelajaran Pemberdayaan

Masyarakat Melalui Teknologi

Cetak Saring Untuk Pembuatan

Souvenir Sebagai Upaya

Peningkatan Kunjungan

Wisatawan Di Desa Wisata

Betisrejo, Sragen. Batoboh, 2(2), 99-

108. https://journal.isi-

padangpanjang.ac.id/index.php/Ba toboh/article/view/353

Sitohang, S., \& Endang, C. (2020).

BATOBOH Jurnal Pengabdian

Pada Masyarakat Pembinaan

Administrasi Dengan

Memanfaatkan Software

Application. Batoboh, 5(2), 78-86.

https://journal.isi-

padangpanjang.ac.id/index.php/Ba toboh

Yunus, N. R., \& Rezki, A. (2020).

Kebijakan Pemberlakuan Lock

Down Sebagai Antisipasi

Penyebaran Corona Virus Covid- 
19. SALAM: Jurnal Sosial Dan

Budaya Syar-I, 7(3), 227-238.

https://doi.org/10.15408/sjsbs.v7i3.1

5083 